\title{
Articles
}

\section{Glucose Transport in Cultured Animal Cells: An Exercise for the Undergraduate Cell Biology Laboratory}

\author{
Mary Lee S. Ledbetter* and Malcolm J. Lippert ${ }^{\dagger}$
}

Department of Biology, College of the Holy Cross, Worcester, Massachusetts 01610

Submitted November 27, 2001; Revised May 6, 2002; Accepted May 23, 2002

Monitoring Editor: Samuel Ward

\begin{abstract}
Membrane transport is a fundamental concept that undergraduate students of cell biology understand better with laboratory experience. Formal teaching exercises commonly used to illustrate this concept are unbiological, qualitative, or intricate and time consuming to prepare. We have developed an exercise that uses uptake of radiolabeled nutrient analogues by attachment-dependent animal cells cultured on multiwell trays. This system can readily be manipulated within a typical 3-h laboratory period to yield reproducible, biologically relevant, quantitative data regarding key aspects of membrane transport. Each 24-well tray of cultures allows a group of two to four students to compare eight conditions in triplicate. If different groups of students test different conditions or different types of cells, data can be shared for an even broader experience. The exercise is also readily adaptable for open-ended student projects. Here we illustrate the exercise measuring uptake of the nonmetabolizable glucose analogue $\left[{ }^{3} \mathrm{H}\right]$-2-deoxy-D-glucose. Students successfully tested the effects of competing sugars, putative inhibitors of the GLUT1 transporter, and changes in cell physiology that might be expected to affect glucose transport in epithelial cells and fibroblasts. In this exercise students find the nutritional and medical implications of glucose transport and its regulation intriguing. They also learn to handle radioisotopes and cultured cells.
\end{abstract}

Keywords: undergraduate, glucose transport, laboratory exercise, cultured animal cells.

\section{INTRODUCTION}

At College of the Holy Cross, Cell Biology is a one-semester course taught to as many as 40 sophomores with previous laboratory courses in introductory biology, organic chemistry, and frequently genetics. The course is held three times a week for lecture and discussion based on reading assignments in Molecular Biology of the Cell (Alberts et al., 1994). Laboratory sections meet weekly for $3 \mathrm{~h}$ for students to carry out exercises designed and adapted to illustrate important concepts and techniques being discussed in lecture and in the textbook chapter entitled "How Cells Are Studied." The topics covered range from microscopy to molecular biology. The goal of each exercise is threefold:

1. To engage students in hands-on application of otherwise abstract concepts and thereby facilitate their learning

DOI: $10.1187 /$ cbe.01-11-0002

*Corresponding author. E-mail address: mledbett@holycross.edu. ${ }^{+}$Current address: St. Michael's College, Department of Biology, Colchester, VT 05439.
2. To help students learn basic techniques and instrumentation that they will encounter again in our curriculum and in research experiences here and elsewhere

3. To give students practice in moving from raw numerical or descriptive data to the appropriate critical generalizations that are fundamental in all of biology, with proper appreciation for variability and significance

In this article we describe one such exercise: the uptake of glucose by cultured animal cells. As described, we consider it an exercise, not an experiment, because students encounter the material through a prescribed procedure and reagents prepared for them. Nevertheless it can be adapted for projectoriented experiences that more closely model true hypothesisdriven experimentation. Even in the form of an exercise, it satisfies the goals of the course.

Membrane transport is an essential concept in cell biology courses. Because most concepts are much more effectively learned when students have the chance to apply them, laboratories accompanying undergraduate cell biology courses generally attempt to include at least one exercise that illustrates 
key principles of membrane transport. Such an exercise must fit within the constraints of time (ordinarily 3-4 h once a week), of high enrollments (multiple sections of as many as 24 students each), and of the inevitable limitations of preparation time, money, and equipment.

Various strategies have been devised to attempt to overcome these limitations. Students can use dialysis tubing as model membranes, observing the progress of reactions that depend on selective diffusion of small molecules, but not large ones, across the tubing walls (e.g., a starch solution inside the dialysis bag and an iodine-potassium iodide solution initially on the outside; see Fleiszar and Wallace, 1985, and Abramoff and Thompson, 1994). The proper choice of solute concentrations even allows this system to illustrate the principles of osmosis as well as diffusion and size selectivity, but as a model for actual cell membranes, it does not readily engage the students.

Another relatively simple model membrane is the mammalian erythrocyte (Abramoff and Thompson, 1994). As solutes enter the cell, the osmotic flux of water causes hemolysis, a clearly identifiable end point. The loss of turbidity of the cell suspension can be used to compare the isotonic concentrations of various solutions and the rate at which related solutes penetrate the erythrocyte membrane. Numerical data can even be gathered by using a spectrophotometer to monitor turbidity as a function of time. Nevertheless the transport parameters depend more on the lipid permeability of the test agents than on the selectivity of membrane proteins and therefore illustrate diffusion more than the specific protein-mediated transport that is so essential to cell function.

A third preparation is the everted intestinal sac (Packer, 1967). Using fresh-killed hamsters or guinea pigs, the student dissects out the small intestine, cuts it into a series of segments, and gently turns each segment inside out. Tying off one end forms a sac into which buffer with various inhibitors can be placed in contact with the serosal surface; then the open end of the sac is tied off. The filled sac with exposed mucosa is placed into a solution of transportable and assayable material and incubated for a period, after which the sac is removed, washed, and opened for analysis of its contents. This system represents authentic living cell membranes engaged in physiologically relevant transcellular transport, but it has numerous drawbacks. First, the sacs are delicate and are frequently damaged during eversion or incubation (as can be detected with a nonpermeant tracer dye). Second, the sacs vary in size, so an additional measure of the area of transporting epithelium is needed for quantitative results to be interpretable. Third, considerable skill is needed to prepare the sacs fast enough to maintain a viable system. Finally, the limited amount of material restricts the comparisons that can be made and the cost in animals is difficult to justify.

We therefore devised a new system based on our experience with cultured animal cells that grow attached to a plastic substrate. This mode of growth is convenient because the cells remain attached as the medium bathing them is changed. Using multiwell cell culture trays makes it easy to treat replicate cultures in different ways, so students have a chance to explore various influences on transport. Transport substrates can be purchased with a tritium label, which permits their sen- sitive detection and affords students the chance to work with radioactivity. In addition, by replicating treatments, students become accustomed to managing and minimizing the variability that accompanies most biological experimentation.

This article describes the exercise using uptake of the glucose analogue $\left[{ }^{3} \mathrm{H}\right]$-2-deoxy-D-glucose and provides background information on preparation of materials to assist instructors who want to use this exercise. The use of radioactivity in an undergraduate teaching laboratory is not a trivial undertaking. If proper precautions are followed, however, the merits of this exercise greatly outweigh the concern; our students have completed it successfully and safely many times. Furthermore, the levels of isotope used are below the level of regulatory concern $(<6 \mu \mathrm{Ci})$ and may be purchased without a license. If concern remains, trained instructors can perform the steps involving introduction of isotope into the cultures and the initial washes.

When possible, we make two types of cells available: fibroblastic and epithelial. The students select their test solutions on the basis of predictions as to how the former type might demonstrate properties of connective tissue (see Inman and Colowick, 1987; Lever, 1987; Bell et al., 1990; Thorens et al., 1990; Thorens, 1993; Klip et al., 1994; Mueckler, 1994) and the latter type might represent a transporting epithelium (see Kimmich and Randles, 1981; J.K. Wright et al., 1986; Ohta et al., 1990; Thorens et al., 1990; E.M. Wright, Hanger et al., 1992; Kong et al., 1993; Thorens, 1993; E.M. Wright, 1993; E.M. Wright, Loo et al., 1996). In addition some of the cells in each tray can be fed the day before the experiment while the rest remain starved. Different types of cells are reported to respond differently to this treatment, some showing stimulation of glucose transport, and others inhibition (Ohta et al., 1990; Klip et al., 1994).

\section{MATERIALS AND METHODS}

\section{Cells and Culture Conditions}

Although prior experience of the instructor with mammalian cell cultures is helpful, it is not essential because cells need to be maintained for only a short term. In principle, any reasonably hardy, available cell type can be used as long as it attaches firmly to its substrate. If no convenient colleague is actively culturing mammalian cells, they can be obtained as frozen ampules from the American Type Culture Collection (Manassas, VA) and placed in culture as needed. We have used the following cell lines during the past decade: MDCK (Madin-Darby canine kidney, epithelial); HaK (hamster kidney epithelial); LLC-PK 1 (pig kidney epithelial); $3 \mathrm{~T} 3$ (mouse embryonic fibroblast); $\mathrm{HF}$ (human foreskin fibroblast); $\mathrm{C}_{2} \mathrm{C}_{12}$ (mouse myoblast); and HeLa (human cervical carcinoma). Depending on the cell type selected, such factors as the cells' nutritional requirements, growth rate, and tolerance of confluence must be considered. For example, fibroblasts form a confluent monolayer and then arrest their growth for an extended period, and they tolerate nutrient limitation, whereas epithelial cells detach from the substrate if they are starved and $\mathrm{C}_{2} \mathrm{C}_{12}$ cells undergo myogenesis. Thus it is important to plan for the optimum physiological status of the cells at the time they are to be tested.

We ordinarily use cells that have formed a confluent monolayer over at least $6 \mathrm{~d}$ of prior culture and for which the medium has not been changed for several days before the laboratory period in which they are to be used. This way, minor inconsistencies in original inoculation of the wells become irrelevant. Occasionally, when it is a planned comparison, the medium of some of the wells in each tray is 
changed ("fed") on the morning of the lab exercise as a way to model nutritionally replete culture conditions.

One 24-well tray (Corning, Corning, NY) is prepared for each group of three to four students. In our laboratories there are usually four to six groups in each of two sections. It is helpful to prepare several extra trays to guard against mishaps. We inoculate $1 \mathrm{ml}$ of the growth medium in each well with cell suspension, prepared in a single large batch to ensure uniform seeding density. A wide range of cell densities is acceptable for most cell lines; we customarily suspend the contents of a subconfluent $60-\mathrm{mm}$ stock culture in $1.0 \mathrm{ml}$ trypsin-EDTA (ethylenedinitrilo tetraacetic acid) and then add the suspension to a sterile tube or bottle containing $50-200 \mathrm{ml}$ of prewarmed growth medium. This amount is enough for four to eight trays and can be scaled up or down as needed. A recent preparation of MDCK cells used $2 \times 10^{4}$ cells/well.

The cells are grown at $37^{\circ} \mathrm{C}$ in a suitable nutrient medium. We use Dulbecco's modified Eagle medium (Gibco, Grand Island, NY) supplemented with $10 \%$ fetal calf serum (Hyclone, Logan, UT) and $10 \mu \mathrm{g} / \mathrm{ml}$ gentamicin (Gibco). This medium is designed to be used in an atmosphere of $5 \% \mathrm{CO}_{2}$ in air, as provided by our incubator. If cell culture facilities are lacking, cells can be grown in HEPES ( $N$-2-hydroxyethylpiperazine- $N$-ethanesulfonic acid)-buffered media or in incubated desiccators purged with $5 \% \mathrm{CO}_{2}$ in air. The cultures should be examined periodically during the growth period to ensure that they remain healthy and uncontaminated.

The medium is changed every 3 to $4 \mathrm{~d}$, on a schedule to prepare the cells properly for the day of the exercise. Medium change involves suctioning off the spent medium and replacing it with an equal volume of prewarmed fresh medium.

\section{Preliminary Instruction to Students}

Through either written instructions or a preliminary discussion, students need to be oriented to the task at hand and advised on unfamiliar procedures. In this exercise, instruction can include additional background information on membrane transport, an introduction to the types of cells to be used in the exercise, an explanation of the purpose of each step, and, most important, instruction on the proper handling of radioisotopes. This latter instruction can fulfill the instructional requirements of an institutional radiation license (Nuclear Regulatory Commission inspector, personal communication).

In the laboratory each group has a designated work area with one part of the bench surface marked off with radioactivity tape (see Appendix for detailed notes on laboratory setup, solution composition, and preparation). In addition to solutions and equipment, each work area includes a beaker for liquid radioactive waste and a plastic bag for solid waste, both labeled with radioactivity tape. Students are instructed to work over the designated area when they are handling isotopically labeled material. This way, spills can be monitored, contained, and cleaned up by using water-soluble materials, whose disposal in the sanitary sewers is generally permitted at these low levels. (We recommend that each instructor consult with the institution's radiation safety officer to learn the limits and procedures for the institution, which are based on Nuclear Regulatory Commission (NRC) guidelines, volume of sewage, and in some cases local or statewide ordinances. If disposal arrangements are already in place, the incremental cost of disposal associated with this exercise should be minor.) Glassware used to collect waste is washed thoroughly with decontaminating solution. Disposable materials that have had contact with isotope are soaked in a basin of decontaminating solution and then discarded. The decontaminating solution is assayed for radioactivity (counted) before disposal.

Each group is provided with all needed solutions at the bench (see Appendix) except for the flask of assay buffer and the tubes of test media, which are initially placed at $37^{\circ} \mathrm{C}$, and the stock solution of radioisotope, which is kept by the instructor until the students are ready for it.

\section{Procedure}

This procedure has been designed to give interpretable results from a variety of cells provided at a variety of densities with minimum use of radioisotope. It is outlined in the flowchart in Figure 1; if students prepare their own flowcharts, they will have a clearer understanding of the manipulations.

Each group of students selects a tray of cells prepared by the instructor. If more than one type of cell is available, the students can choose among them. The instructor should draw their attention to the designations of the rows of the tray as A through $\mathrm{D}$ and the columns as 1 through 6, so that students can keep accurate records of the treatments of the various wells. The students should be informed as to how the cells have already been treated (i.e., grown to confluence or not, actively growing or quiescent, recently fed or not). They may also benefit from a discussion of how they might predict, on the basis of the published literature, each cell type's behavior.

From this point on, cells need not be handled with sterile technique because the manipulations take only an hour. The first step is to wash off the growth medium without perturbing the cells or their growth temperature. Students retrieve a warm flask of assay buffer (KrebsRinger phosphate buffer with Tris and albumin, $\mathrm{pH}$ 7.45). Well by well, they remove the growth medium with a plastic transfer pipette and replace it with $1.0 \mathrm{ml}$ warm assay buffer. We find it helpful to use simple automatic pipetters to dispense volumes between 0.1 and $1.0 \mathrm{ml}$ reproducibly and reasonably accurately; the pipetters and their disposable tips are relatively inexpensive. The cells must not dry out,

\section{Multiwell tray of cells}

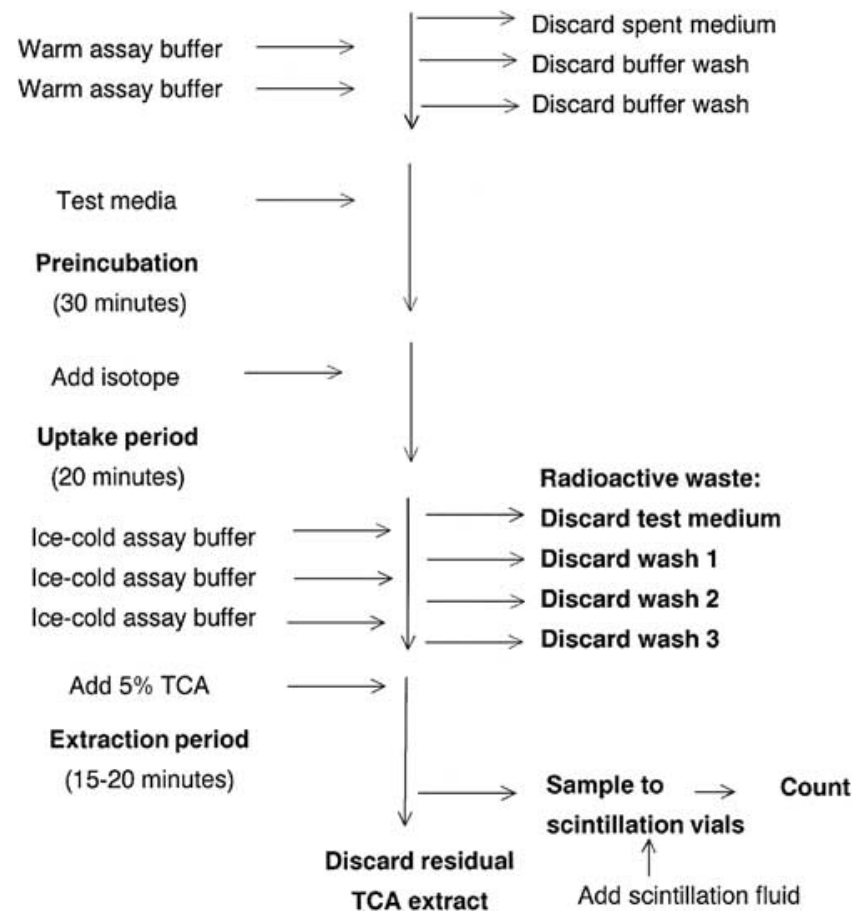

Figure 1. Flowchart summarizing the membrane transport assay procedure. Additions to the culture wells are given on the left and withdrawals on the right. Boldface type on the left designates incubation periods; boldface type elsewhere designates solutions that contain radioactivity and that should be handled accordingly. TCA, trichloroacetic acid. 
so as soon as one solution has been removed, the next must be added. When all wells have been washed once, the process is repeated with a second $1.0-\mathrm{ml}$ portion of warm assay buffer.

Next the assay buffer in each well is replaced with $0.4 \mathrm{ml}$ of the appropriate warm test media, three wells receiving each medium, and the tray is placed at $37^{\circ} \mathrm{C}$ in room atmosphere for $30 \mathrm{~min}$. During this preincubation period the cells adjust their physiology in response to the test media. Test agents may include hormones (insulin, epidermal growth factor, dexamethasone, aldosterone), inhibitors (phloridzin, phloretin, ouabain, cytochalasin B), competing sugars (glucose, galactose, mannose, fructose, sucrose, mannitol, xylose), or any variations on the theme that seem scientifically interesting. All test reagents are prepared in advance in assay buffer. Students can select which test media to use for which wells (and later defend their choices with a reasonable rationale), or the instructor can designate the media to be tested. If the students are doing independent projects, they can plan and prepare their own test media.

Deoxyglucose is recognized by the glucose transporter GLUT1 and it is phosphorylated by hexokinase (Kimmich and Randles, 1976), but its missing hydroxyl group prevents its further metabolism, and thus allows it to accumulate intracellularly. After the 30-min preincubation the students don disposable gloves and plastic aprons, remove their trays from the incubator, take a tube containing 2.5$3.0 \mathrm{ml}$ of $\left[{ }^{3} \mathrm{H}\right]$-2-deoxy-D-glucose $(2.0 \mu \mathrm{Ci} / \mathrm{ml} ; 2.0 \mu \mathrm{Ci} / \mu \mathrm{mol})$ from the instructor, and, working over the designated area of the lab bench, transfer $0.1 \mathrm{ml}$ of it to each of their 24 wells, noting the time at the beginning and at the end of the addition. Randomizing the order of addition of isotope to wells can minimize timedependent systematic error, although doing so will increase random error.

The trays are next returned to the incubator for the uptake period, the time is noted again. The nearly empty tube of isotope is returned to the instructor and the plastic tip used to dispense isotope is placed in the waste bag. The trays are incubated for $20 \mathrm{~min}$. During this period the students chill their assay buffer and a flask of $5 \%$ trichloroacetic acid (TCA) on ice and make sure that the waste beaker is ready to receive radioactive liquid.

At the end of the uptake period the trays are removed from the incubator, the time is noted, and the medium in each well is removed and replaced rapidly three times with $1 \mathrm{ml}$ of ice-cold assay buffer. Although it takes longer to rinse each well in turn than to rinse all the wells once, then a second and a third time in sequence, the former procedure prevents the isotope leakage that might occur if the cells spent extended periods in cold assay buffer. Students working in teams can efficiently change the medium if one withdraws and another immediately adds fresh.

After the third rinse the last drops of assay buffer are removed from the well; all the remaining radioactivity in the wells should be inside the cells. Next $0.5 \mathrm{ml}$ ice-cold 5\% TCA is added to precipitate macromolecules and extract small molecules, including the radiolabeled deoxyglucose. The tray is placed on ice for 15 to $20 \mathrm{~min}$ to ensure complete extraction. Then $0.4 \mathrm{ml}$ is sampled from each well to a corresponding scintillation vial. Two extra vials are prepared: one containing $0.4 \mathrm{ml}$ of the 5\% TCA alone (background) and the other containing a cotton swab that has been moistened with water and wiped over the designated work surface. All the scintillation vials receive an equal volume of an appropriate scintillation fluid (we use $3.0 \mathrm{ml}$ of Ecoscint from National Diagnostics, Manville, $\mathrm{NJ}$ ), caps are screwed on and marked, and the vials are shaken, and taken for counting. If the institution owns a scintillation counter, it may be demonstrated to interested students along with an explanation of how it works. Otherwise the prepared samples can be collected and stored for a time before they are transported elsewhere for counting.

(An alternative to TCA extraction is to allow the wells to dry and then to dissolve the contents in base, such as $0.1 \mathrm{~N} \mathrm{NaOH}$ with $2 \%$ $\mathrm{Na}_{2} \mathrm{CO}_{3}$. Although this procedure takes longer, the samples are then available for students to use them for standard protein assays as well as scintillation counting, which is potentially desirable as a check on the uniformity of seeding of the wells.)
Before leaving the laboratory for the day, students clean their work area, transferring residual TCA from the trays to their liquid waste, placing the trays in marked plastic bags, and pouring the liquid waste into the jug designated to collect it.

The results of the scintillation counting are made available to the students. In preparing their analysis they first check that their swab test is less than twice the background measured by their TCA control. If not, they notify the instructor, who decontaminates the appropriate area of the bench. They then subtract the background from each sample and calculate the mean counts per minute (cpm) and standard deviation for each triplicate group. This value may be used directly for comparisons with the control. It can also be successively corrected for sampling $(0.4 \mathrm{ml}$ of the total $0.5 \mathrm{ml}$ in the well) and for the time of incubation (assumed to be a uniform 20 min unless the group has more precise data) to generate a value of $\mathrm{cpm}$ taken up per minute. Conversion of $\mathrm{cpm}$ to nanomoles uses the efficiency of tritium counting of the scintillation counter (about $0.45 \mathrm{cpm} / \mathrm{dpm}$ in our instrument), the correspondence of disintegrations per minute $(\mathrm{dpm})$ to microcuries $\left(1 \mu \mathrm{Ci}=2.22 \times 10^{6} \mathrm{dpm}\right.$, the measure of isotope activity), and the specific activity of the isotope $(2.0 \mu \mathrm{Ci} / \mu \mathrm{mol})$. Values of $\mu \mathrm{mol} / \mathrm{min} /$ well with standard deviations are compared.

If different groups have used different cells or tested different conditions, the exercise is easily made collaborative by inviting groups to post their results in the laboratory or on a computer network and asking students to comment about the data that other groups generated. This step is unusually effective as a way to stimulate discussion.

\section{RESULTS}

Figure 2 illustrates the data generated by the nine groups of students in two sections of the cell biology laboratory in March 2000 and by the seven groups in March 2001 at College of the Holy Cross. All groups used MDCK cells and the common set of conditions, as indicated. The test solutions are described in detail in the Appendix. The mean control value was set at $100 \%$ and the relative results for the other seven conditions were calculated in relation to the control. Above each set of results are the average results for the class. The groups generated remarkably consistent results. Within each group there was good reproducibility among triplicates, and discrepant results could generally be attributed to what variability there was.

The expected inhibition of transport by D-glucose was matched by a comparable inhibition in the presence of Dmannose. L-Glucose had no effect, which illustrates the stereospecificity of the transport mechanism. The three inhibitors of the glucose transporters were of different efficacy, with phloretin and cytochalasin B acting much more completely than phloridzin in each experiment. Aldosterone was without effect in most experiments in 2000, as were galactose, fructose, and sucrose in 2001.

Figure 3 illustrates data generated by students in two sections of the cell biology laboratory in the spring of 1999. Four groups of students used MDCK cells and three used LLC-PK 1 , a pig kidney epithelial cell line. MDCK results similar to those of Figure 2 were obtained, although the magnitude of the differences from control values varied from year to year. Notably, LLC-PK 1 cells did not show as complete an inhibition of transport by the competing sugars as did MDCK cells. In addition, neither cell line was affected more by cytochalasin $\mathrm{B}$ than by phloridzin, probably owing to incompletely dissolved cytochalasin during solution preparation. Ouabain alone or in combination with aldosterone had no apparent effect on these cells in most experiments. 


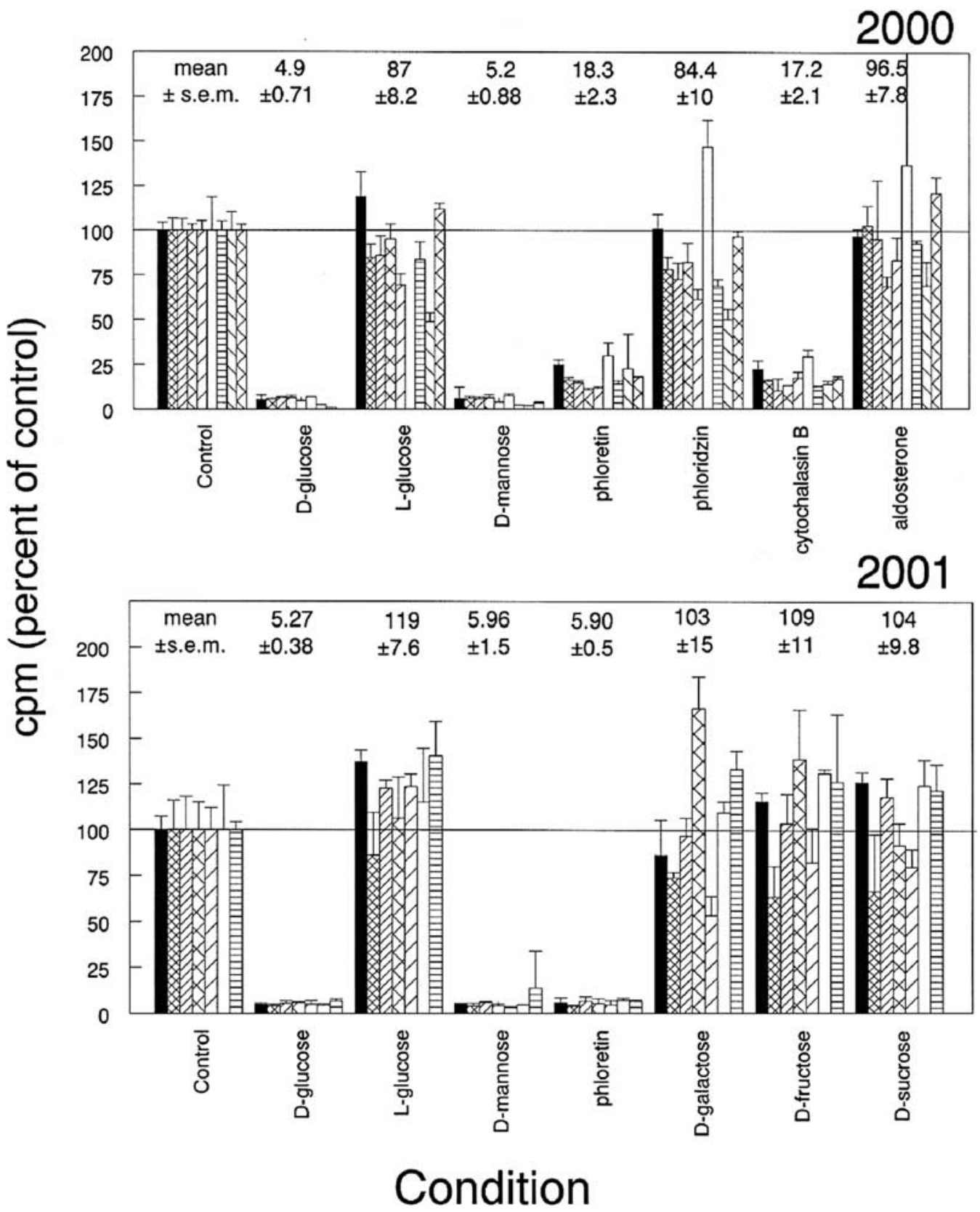

Figure 2. Transport of 2-deoxy-D-glucose by cultured MDCK (dog kidney epithelial) cells. The top panel shows data from five groups on one day and four on the next in March 2000. The bottom panel shows data from four and three groups in March 2001. All students used confluent MDCK cells that had been growing for 5 to $6 \mathrm{~d}$. Each group's data are presented by a bar of a different pattern. Test media are given on the abscissa; the ordinate presents the results expressed relative to the control (assay buffer), which was set to 100\%. Error bars denote standard deviations of the triplicates. Above each set of bars is the mean percent of control for all the groups \pm standard error of the mean (s.e.m.). Values for mean control counts per minute (cpm) ranged from 2465 to 6197 in 2000 and from 3650 to 9250 in 2001.

The results from seven groups of students in the cell biology laboratory in the spring of 1998 are shown in Figure 4. Three groups used normal human fibroblasts (HF) and four used MDCK cells. There is higher intergroup variability in these data, but it can be attributed to a single group (crosshatches).

The data of Figures 2 and 4 were obtained under the supervision of Dr. Ledbetter and those of Figure 3 under Dr. Lippert, according to the procedures outlined in this article.
The procedures are thus readily adapted to various instructors and generate robust data from various cell types.

\section{DISCUSSION}

We presented evidence supported by data from students in four successive years that sophomore undergraduates can use 


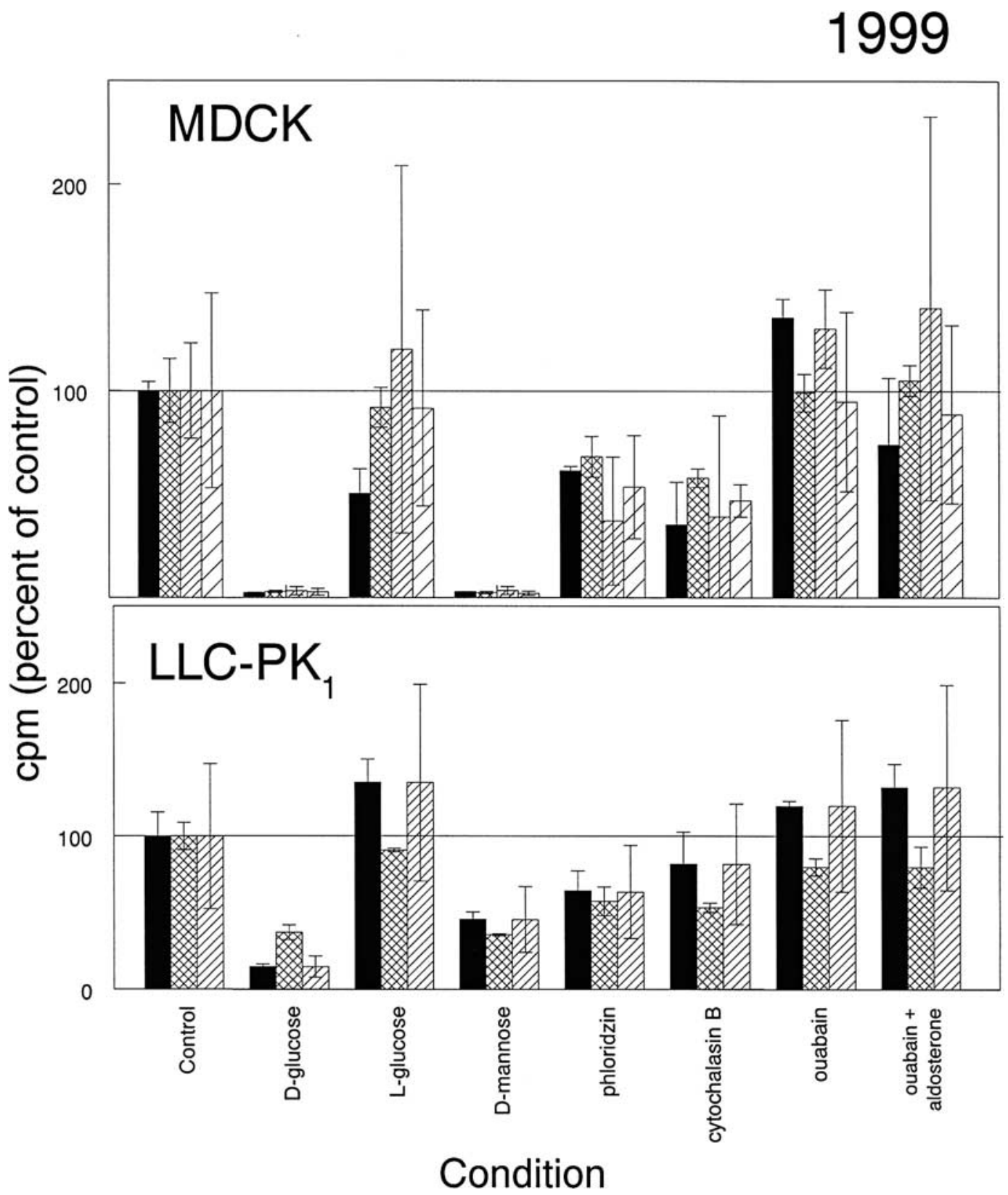

Figure 3. Transport of 2-deoxy-D-glucose by cultured MDCK or LLC-PK 1 (pig kidney epithelial) cells (1999 data). Four groups used MDCK cells and three used LLC-PK 1 cells, prepared and treated as described in the legend for Figure 2 and assayed in the test media identified in the abscissa. The data are presented as in Figure 2. Values for mean control cpm for this iteration of the exercise are not available.

the transport of deoxyglucose into cultured animal cells to discover important principles of membrane transport and factors that influence it. The rationale for the various treatments tested in those 4 years was based on our reading of the literature and on untested hypotheses relating to our research at the time. They are by no means the only possibilities, because it is likely that various influences affect the uptake rate of glucose by cultured cells, in some cases differentially according to cell type.
The most universal finding was that D-glucose and Dmannose, but not L-glucose, competed effectively for transport of 2-deoxyglucose by all the cells tested. Membrane transport mechanisms are assumed to have specificity, but it is not surprising to find this degree of cross-reactivity. Students could explore further variations on the structure of the sugar offered as competitor for the radiolabeled deoxyglucose and discover for themselves exactly how far the specificity extends as well as compare it in multiple cell types. For example, 


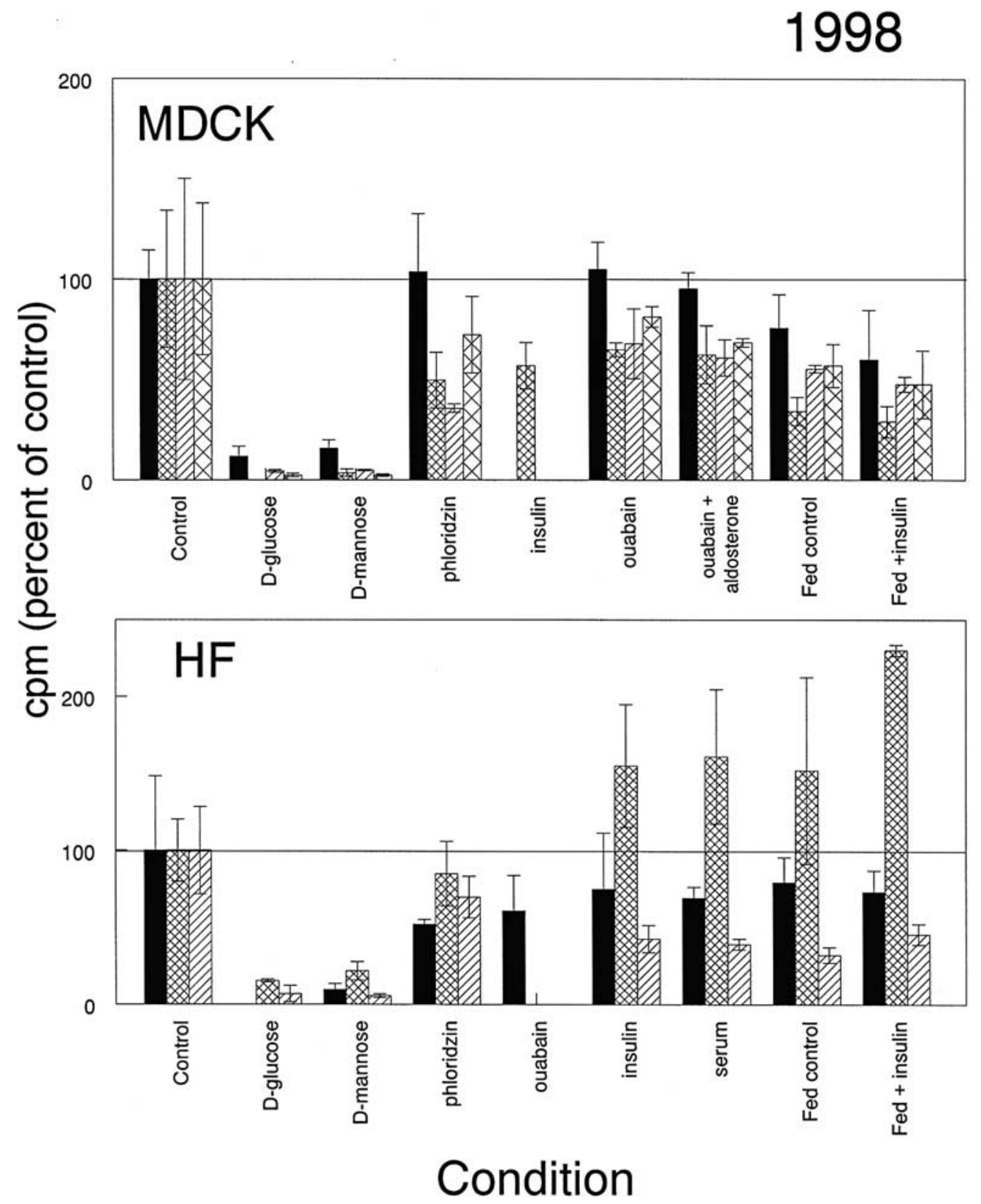

Figure 4. Transport of 2-deoxy-D-glucose by cultured MDCK cells or human fibroblasts (HF). Cells were prepared and treated as described in the legend for Figure 2, except that for some trays, six of the wells had the medium changed the day before the laboratory period ("Fed"). The mean value for unfed cells not otherwise treated was set to $100 \%$ in each group, and the remaining values for that tray were expressed as percent of unfed control \pm standard deviation. Data are presented from all but two of the groups in two laboratory sections. One of the omitted groups had results so low (and consequently variable) that we assume either that their wells were underpopulated with cells or that the students added an incorrect amount of isotope. The other group failed to include a control among the conditions they tested. The value for mean cpm taken up in control MDCK cells ranged from 4617 to 6702; for HF cells it ranged from 1329 to 2370.

fructose is reported not to be transported by the GLUT1 transporter but is favored by GLUT2 and GLUT5 (Thorens, 1993). The failure of fructose to compete for transport in MDCK cells (Figure 2, 2001 data) supports the notion that these cells express GLUT1.
We initially chose phloridzin as a specific inhibitor of the glucose transporter protein. We selected it in part because of its relatively low cost. Surprised to see only a modest inhibition, we checked further and learned that it is a better inhibitor of sodium-linked transport (Kimmich and Randles, 1981) 
than of the sodium-independent transport expressed by the cell types we were using. Phloretin and cytochalasin B, both reported to be strong inhibitors of transport by the sodiumindependent (GLUT1) mechanism (Sogin and Hinkle, 1980; Thorens et al., 1990; Thorens, 1993), gave much better inhibition than phloridzin did in MDCK cells. Thus the exercise can be continuously refined and focused as more is learned.

We surmised that kidney-derived cell lines, such as MDCK and LLC-PK 1 , might exhibit sodium-linked glucose transport. If so, transport should slow in cells whose sodium pump had been inhibited by ouabain, which would reflect a shallower sodium gradient available to power glucose uptake. We failed to see evidence of such inhibition in either cell line. MDCK cells are reported not to express SGLT1, the sodium-glucose cotransporter (Kong et al., 1993), which is consistent with our results. LLC-PK 1 cells are taken as a culture model for the proximal tubule of the kidney, where sodium-linked glucose transport is an important mechanism for glucose retrieval from the urinary filtrate (Ohta et al., 1990). We do not know whether these cells express SGLT1 or not. Even if they do, however, there are several explanations for our failure to detect it. The ouabain exposure might have been too brief to change ion gradients significantly. In addition deoxyglucose is reported not to serve as a substrate for the intestinal $\mathrm{Na}^{+}$/glucose cotransporter (Wright, 1993) and thus also might not work for SGLT1. We chose deoxyglucose as the glucose analogue because it is recognized by the glucose transporter and phosphorylated by hexokinase (Kimmich and Randles, 1976) but not further metabolized owing to the missing hydroxyl group. Another commonly used nonmetabolizable analogue, 3-O-methylglucose, is recognized by the intestinal cotransporter. However, it is not phosphorylated; it equilibrates across the cell membrane (Inman and Colowick, 1987), which limits the time available for measurements of unidirectional uptake.

Aldosterone, reported to exert its mineralocorticoid activity by stimulating the sodium pump and its synthesis, likewise had no effect on our system. Various explanations include trivial issues of dosage and time as well as more significant considerations regarding responsiveness of the cultured cells and linkage of the response to glucose transport.

Insulin is reported to stimulate glucose uptake along with proliferation in starved fibroblasts (Mueckler, 1994) and may be able to promote translocation to the plasma membrane of the GLUT4 transporter (Inman and Colowick, 1987; Lever, 1987; Kasanicki and Pilch, 1990; Thorens et al., 1990; Klip et al., 1994). Insulin-responsive glucose transport, ascribed to GLUT4, is said to be limited to adipocytes and muscle cells (Bell et al., 1990), but in the past we have seen responsiveness of human fibroblasts (M.R. Rosholt, unpublished results; see also Klip et al., 1994). Results from different groups of students were highly inconsistent, ranging from transport rates lower than that of the control to apparently stimulated transport (although in the latter case there was substantial internal variability). We assumed that any effect of insulin might be mimicked by serum, otherwise absent from the assay buffer, but in this case, too, results were not conclusive.

Changing the medium in the $24 \mathrm{~h}$ before measuring uptake made little consistent difference in uptake. We had thought that feeding might stimulate growth and thus increase the need for nutrient uptake, but it might also provide higher internal nutrient levels to begin with and thus attenuate facilitated diffusion. Neither hypothesis is clearly supported by the data.

Students responded favorably to this exercise. Their group reports showed thoughtful analysis of the data, care in considering sources of error, and imagination in interpreting the results. They rose to the challenge of handling radioisotopes, and this feature of the exercise lent a touch of glamour to the proceedings. They were impressed that replicability of results (both within their triplicate measurements and among different groups testing the same variables) adds to the confidence with which researchers can reach conclusions. Finally, they appreciated that glucose uptake is a significant cellular event, of importance not only as an example of membrane transport but also as an essential element of cellular and organismal nutrition.

Possibilities for varying this exercise are almost unlimited. In some years students used it for 3-week projects at the end of the semester, designing their own comparisons among these or other cell lines on the basis of their reading of the literature. One student took our claim that transporters were analogous to enzymes seriously and undertook to measure the $\mathrm{K}_{\mathrm{m}}$ and $\mathrm{V}_{\max }$ of the mouse 3T3 uptake system. She used solutions of constant specific activity but eight different absolute deoxyglucose concentrations. She interpreted her results with a Lineweaver-Burk double-reciprocal plot to extrapolate kinetic parameters very close to those in the literature (Simpson and Cushman, 1986).

In summary, uptake of radiolabeled substrates provides an effective basis for laboratory exercises illustrating membrane transport mechanisms. The exercises are relevant to important research questions in cell physiology, provide interpretable quantitative data, and can be accomplished within the constraints prevailing in most undergraduate laboratory settings.

\section{REFERENCES}

Abramoff, P., and Thompson, R.G. (1994). Laboratory Outlines in Biology, 6th ed., New York: Freeman, 67-68.

Alberts, B., Bray, D., Lewis, J., Raff, M., Roberts, K., and Watson, J.D. (1994). Molecular Biology of the Cell, 3rd ed., New York: Garland.

Bell, G.I., Kayano, T., Buse, J.B., Burant, C.F., Takeda, J., Lin, D., Fukumoto, H., and Seino, S. (1990). Molecular biology of mammalian glucose transporters. Diabetes Care 13, 198-208.

Fleiszar, K.A., and Wallace, B.J. (1985). Introductory Experiments in Cell Biology, 2nd ed., Winston-Salem, NC: Hunter Textbooks, 4764 .

Inman, W.H., and Colowick, S.P. (1987). Growth factor stimulation of sugar uptake. Methods Enzymol. 146, 399-402.

Kasanicki, M., and Pilch, P.F. (1990). Regulation of glucose-transporter function. Diabetes Care 13, 219-227.

Kimmich, G.A., and Randles, J. (1976). 2-Deoxyglucose transport by intestinal epithelial cells isolated from chick. J. Membrane Biol. 27, 363-379.

Kimmich, G.A., and Randles, J. (1981). $\alpha$-Methylglucoside satisfies only $\mathrm{Na}^{+}$-dependent transport system of intestinal epithelium. Am. J. Physiol. 241 (Cell Physiol. 10), C227-C232. 
Klip, A., Tsakiridis, T., Marette, A., and Ortiz, P.A. (1994). Regulation of expression of glucose transporters by glucose: a review of studies in vivo and in cell cultures. FASEB J. 8, 43-53.

Kong, C.-T., Varde, A., and Lever, J.E. (1993). Targeting of recombinant $\mathrm{Na}^{+}$/glucose cotransporter (SGLT1) to the apical membrane. FEBS Lett. 333, 1-4.

Lever, J. (1987). Growth factor effects on membrane transport: uptake studies using cell cultures and isolated membrane vesicles. Methods Enzymol. 146A, 376-383.

Mueckler, M. (1994). Facilitative glucose transporters. Eur. J. Biochem. $219,713-725$.

Ohta, T., Isselbacher, K.J., and Rhoads, D.B. (1990). Regulation of glucose transporters in LLC-PK 1 cells: effects of D-glucose and monosaccharides. Mol. Cell. Biol. 10, 6491-6499.

Packer, L. (1967). Experiments in Cell Physiology, New York: Academic Press, 229-235.

Simpson, I.A., and Cushman, S.W. (1986). Hormonal regulation of mammalian glucose transport. Annu. Rev. Biochem. 55, 10591089.

Sogin, D.C., and Hinkle, P.C. (1980). Binding of cytochalasin B to human erythrocyte glucose transporter. Biochem. 19, 5417-5420.

Thorens, B. (1993). Facilitated glucose transporters in epithelial cells. Annu. Rev. Physiol. 55, 591-608.

Thorens, B., Charron, M.J., and Lodish, H.F. (1990). Molecular physiology of glucose transporters. Diabetes Care 13, 209-218.

Wright, E.M. (1993). The intestinal sodium/glucose cotransporter. Annu. Rev. Physiol. 55, 575-589.

Wright, E.M., Hager, K.M., and Turk, E. (1992). Sodium cotransport proteins. Curr. Opin. Cell Biol. 4, 696-702.

Wright, E.M., Loo, D.D.F., Turk, E., and Hirayama, B.A. (1996). Sodium cotransporters. Curr. Opin. Cell Biol. 8, 468-473.

Wright, J.K., Sackler, R., and Overath, P. (1986). Molecular aspects of sugar:ion cotransport. Annu. Rev. Biochem. 55, 225-248. 


\section{Appendix}

\section{Notes for Laboratory Preparation}

1. For each group of students, equip a station with

- Beaker for radioactive waste with a piece of radioactivity tape on it

- Small plastic bag (such as a quart- or pint-sized freezer bag) with a piece of radioactivity tape on it, for solid waste

- Racks for 26 scintillation vials (If your counter uses special racks, you can provide the vials in the racks.)

- 26 minivials and caps

- 5- and 10-ml pipettes to use for washes and Brinkman propipette

- Pipette guns and tips (Clay-Adams Selectapette) (Fisher Scientific, discontinued)

- 2 plastic disposable transfer pipettes, one with flag of radioactivity tape

- Ice bucket (fill just before lab)

- 3-ft square of bench taped off with radioactivity tape

2. At an accessible spot in the room, place

- Roll of radioactivity tape

- One box each of small, medium, and large disposable gloves and plastic disposable aprons

- Package of cotton swabs (Q-Tips) for swab tests

3. Prepare a standard incubator to operate at about $37^{\circ} \mathrm{C}$.

4. Equip a fume hood or other out-of-the-way location with

- 4.0-1 brown jug with a piece of radioactivity tape on it and labeled "Liquid Radioactive Waste Here," placed on a piece of absorbent lab-bench paper large enough to catch any spills

- Dispensing bottle of scintillation fluid set to dispense the appropriate volume

5. In the sink, place

- A basin of water with a squirt of Radiac Wash (Biodex Medical Systems, Shirley, NY) and a sign "Radioactive Glassware Here"

- A small carboy with Radiac Wash in tap water, labeled "Decontamination Solution"

- A sponge

6. Prepare the following solutions:

20X Stock Solutions (mixed in various proportions to make the final solutions so that it is easier to replenish supplies that run low)

\begin{tabular}{|c|c|c|c|}
\hline Concentration & $\begin{array}{c}\text { Grams to } \\
\text { weigh }\end{array}$ & $\begin{array}{l}\text { Distilled } \\
\text { water } \\
(\mathrm{ml})\end{array}$ & $\begin{array}{l}\text { Concentration } \\
\text { in 1X (after } \\
\text { dilution) }\end{array}$ \\
\hline $2.32 \mathrm{M} \mathrm{NaCl}$ & 33.9 & 250 & $116 \mathrm{mM}$ \\
\hline $108 \mathrm{mM} \mathrm{KCl}$ & 2.0 & 250 & \\
\hline $16 \mathrm{mM} \mathrm{MgSO} \cdot 7 \mathrm{H}_{2} \mathrm{O}$ & 1.0 & 250 & 0.8 \\
\hline $20 \mathrm{mM} \mathrm{CaCl}_{2} \cdot 2 \mathrm{H}_{2} \mathrm{O}$ & 0.75 & 250 & 1.0 \\
\hline $0.50 \mathrm{M}$ Trizma-HCl & 19.75 & 250 & \\
\hline $4 \%$ Bovine serum albumin & 10.0 & 250 & $0.2 \%$ \\
\hline $20 \mathrm{mM} \mathrm{NaH}_{2} \mathrm{PO}_{4}$ & $\begin{array}{c}25 \mathrm{ml} \text { of } \\
0.2 \mathrm{M}\end{array}$ & 225 & 1.0 \\
\hline $40 \mathrm{mM} \mathrm{Na}_{2} \mathrm{HPO}_{4} \cdot 7 \mathrm{H}_{2} 0$ & $\begin{array}{r}50 \mathrm{ml} \text { of } \\
0.2 \mathrm{M}\end{array}$ & 200 & 2.0 \\
\hline
\end{tabular}

We keep $0.2 \mathrm{M}$ sodium phosphate solutions on hand all semester. They are prepared as follows:

- Stock $0.2 \mathrm{M} \mathrm{NaH}_{2} \mathrm{PO}_{4}$ : Dissolve $8.34 \mathrm{~g} \mathrm{NaH} \mathrm{PO}_{4} \cdot \mathrm{H}_{2} \mathrm{O}$ in $300 \mathrm{ml}$ distilled water.

- Stock 0.2 $\mathrm{M} \mathrm{Na}_{2} \mathrm{HPO}_{4}$ : Dissolve $16.10 \mathrm{~g} \mathrm{Na}_{2} \mathrm{HPO}_{4} \cdot 7 \mathrm{H}_{2} \mathrm{O}$ in $300 \mathrm{ml}$ distilled water.

Assay Buffer (Krebs-Ringer Phosphate with Tris and Albumin, pH 7.45)

In a 4-1 flask, mix $200 \mathrm{ml}$ of each of the above solutions, except the $\mathrm{CaCl}_{2}$. Add 2.01 of distilled water. Adjust the $\mathrm{pH}$ to 7.45 if necessary. While stirring vigorously, add 200 $\mathrm{ml} \mathrm{CaCl} 2$. It should not precipitate. Bring final volume to 4.01 .

Dispense $\sim 300 \mathrm{ml}$ to stoppered Erlenmeyer flasks, one per group. Label "Assay Buffer" and store in the cold room with the remnants of the 20X stock solutions. Before lab, place the flasks in the incubator so that they are at $37^{\circ} \mathrm{C}$ for use. After lab, replenish the flasks for the next period.

TEST MEDIA The following recipes are scaled for $30 \mathrm{ml}$ of solution, ample for seven or eight groups. They can be scaled up or down as demand warrants. After preparing, dispense about $4 \mathrm{ml}$ into the desired number of plastic disposable tubes with snap caps, label, and store in racks in the cold room. Before lab, place at room temperature on the front bench.

\section{Assay Buffer + Phloridzin (0.3 mM)}

This is a convenient way to make accurate solutions with small amounts of precious reagents:

- Weigh out as close as you can to $4.00 \mathrm{mg}$. Dissolve it in $0.3 \mathrm{ml} \mathrm{100 \%}$ ethanol in a microfuge tube.

- Calculate the volume that will yield $4.0 \mathrm{mg} / 30 \mathrm{ml}$ for the mass you weighed.

- Dissolve the ethanol solution into that volume of assay buffer.

\section{Assay Buffer + Phloretin (0.3 mM)}

- Weigh out as close to $2.5 \mathrm{mg}$ as you can. Dissolve it in $0.3 \mathrm{ml} 100 \%$ ethanol in a microfuge tube.

- Calculate the volume that will yield $2.5 \mathrm{mg} / 20 \mathrm{ml}$ for the mass you weighed.

- Dissolve the ethanol solution into that volume of assay buffer.

\section{Assay Buffer + Cytochalasin B (25 $\mu \mathrm{M})$}

- Take an unopened vial of $1 \mathrm{mg}$ cytochalasin B and add to it $83 \mu 1100 \%$ ethanol. Dissolve.

- Pipette $30 \mu \mathrm{l}$ into $30 \mathrm{ml}$ assay buffer.

(Save unused cytochalasin B solution, frozen.)

Assay Buffer + Serum (10\% v/v)

Mix $3.0 \mathrm{ml}$ fetal bovine serum with $27 \mathrm{ml}$ assay buffer.

\section{Assay Buffer + Insulin $(0.1 \mu \mathrm{g} / \mathrm{ml})$}

- Prepare stock insulin: $4.0 \mathrm{mg}$ in $1.0 \mathrm{ml} 0.1-\mathrm{M}$ acetic acid $=4 \mathrm{mg} / \mathrm{ml}$. 
- Predilute stock insulin: $0.1 \mathrm{ml}+9.9 \mathrm{ml}$ assay buffer = $40 \mu \mathrm{g} / \mathrm{ml}$.

- Mix $0.15 \mathrm{ml}$ of this predilution with $60 \mathrm{ml}$ assay buffer.

(Save any extra stocks or predilutions, frozen, for another use.)

\section{Assay Buffer + D- or L-Hexoses ( $5 \mathrm{mM}$ )}

- Weigh out as close as you can to $36 \mathrm{mg}$ D- or L-glucose, mannose, fructose, galactose, and so forth.

- Calculate the volume that corresponds to $36 \mathrm{mg} / 40 \mathrm{ml}$ for the mass you weighed.

- Dissolve that mass into the calculated volume of assay buffer and mix well.

Assay Buffer + Ouabain (0.1 $\mu \mathrm{M})$

- Prepare stock ouabain: Weigh out as close as you can to $7.2 \mathrm{mg}$ of ouabain octahydrate; dissolve it in water to make $3.643 \mathrm{mg} / \mathrm{ml}$. Vortex or heat gently if needed to completely dissolve. This makes a 5-mM stock solution and can be stored frozen.

- Predilute stock 5-mM ouabain to $50 \mu \mathrm{M}$ by mixing 0.1 $\mathrm{ml}$ of 5-mM stock with $9.9 \mathrm{ml}$ assay buffer.

- Add $0.60 \mathrm{ml}$ of this predilution to $29.4 \mathrm{ml}$ assay buffer. Mix well.

Assay Buffer + Aldosterone (0.1 $\mu \mathrm{M})$

- Prepare stock 10-mM aldosterone: 5-mg vial of Daldosterone $+1.387 \mathrm{ml}$ DMSO (dimethyl sulfoxide).

- Prepare serial dilutions:

$0.1 \mathrm{ml}$ of $10 \mathrm{mM}+9.9 \mathrm{ml}$ assay buffer $\rightarrow 100 \mu \mathrm{M}$

$0.1 \mathrm{ml}$ of $100 \mu \mathrm{M}+9.9 \mathrm{ml}$ assay buffer $\rightarrow 1 \mu \mathrm{M}$

$3 \mathrm{ml}$ of $1 \mu \mathrm{M}+27 \mathrm{ml}$ assay buffer $\rightarrow 0.1 \mu \mathrm{M}$

\section{Assay Buffer + Ouabain + Aldosterone}

Use the same predilutions prepared above. Mix the following:

- $0.6 \mathrm{ml} 50-\mu \mathrm{M}$ ouabain

- $3 \mathrm{ml} 1-\mu \mathrm{M}$ aldosterone

- $26.4 \mathrm{ml}$ assay buffer

Sodium-Free Assay Buffer (useful if you plan to test requirement for external sodium for transport, but keep in mind that the radioisotope needs to be prepared in the same sodium-free buffer)
- Stock choline chloride (2.32 M): 3.63 g choline chloride dissolved in $10 \mathrm{ml}$ distilled $\mathrm{H}_{2} \mathrm{O}$

- Stock $\mathrm{KH}_{2} \mathrm{PO}_{4}(20 \mathrm{mM})$ : $27.22 \mathrm{mg} \mathrm{KH} \mathrm{KO}_{4}$ dissolved in $10 \mathrm{ml}$ distilled water

- Stock $\mathrm{K}_{2} \mathrm{HPO}_{4}$ (40 mM): $91.3 \mathrm{mg} \mathrm{K}_{2} \mathrm{HPO}_{4} \cdot 3 \mathrm{H}_{2} \mathrm{O}$ dissolved in $10 \mathrm{ml}$ distilled water

- Mix $2.0 \mathrm{ml}$ of each of these three stocks with $2.0 \mathrm{ml}$ of the following 20X stock solutions: $\mathrm{KCl}, \mathrm{MgSO}_{4}$, bovine serum albumin, and Tris.

- Add $20.0 \mathrm{ml}$ distilled water. Mix well.

- Add $2.0 \mathrm{ml}$ of the $\mathrm{CaCl}_{2}$ stock solution. Mix well.

- Adjust the $\mathrm{pH}$ to 7.45 if necessary.

- Add distilled water to a final volume of $40.0 \mathrm{ml}$.

5\% TCA

Prepare 100\% TCA: Add distilled water to a 100-g bottle of TCA crystals to make $100 \mathrm{ml}$. In our hands $43 \mathrm{ml}$ of water is enough. TCA is so hygroscopic that it is difficult to weigh accurately. Mix $20 \mathrm{ml}$ of $100 \%$ TCA with $330 \mathrm{ml}$ distilled water.

${ }^{3} \mathrm{H}$-2-deoxy-D-Glucose $(2 \mu \mathrm{Ci} / \mathrm{ml} ; 2 \mu \mathrm{Ci} / \mu \mathrm{mol})$

(Note: Small amounts of tritium-labeled compounds can be purchased without a government license.)

You will need $0.1 \mathrm{ml} /$ well $\times 24$ wells/plate $\times 1$ plate $/$ group $\times \mathrm{N}$ groups. Make a little extra to allow for transfer loss. For 14 groups, we usually make $40 \mathrm{ml}$ :

- Prepare 2-deoxyglucose carrier (20-mM stock): $32.8 \mathrm{mg}$ dissolved in $10 \mathrm{ml}$ distilled water.

- Thaw stock radioactive 2-deoxyglucose $(1 \mathrm{mCi} / \mathrm{ml})$.

- Mix $80 \mu \mathrm{l}$ of radioactive 2-deoxyglucose with $2 \mathrm{ml}$ of stock $20-\mathrm{mM}$ carrier and $38 \mathrm{ml}$ assay buffer.

- Dispense 2.5-2.6 ml to a series of snap-cap disposable tubes labeled with radioactivity tape.

Na-Free ${ }^{3} \mathrm{H}$-2-deoxy-D-glucose $(2 \mu \mathrm{Ci} / \mathrm{ml} ; 2 \mu \mathrm{Ci} / \mu \mathrm{mol})$ (for those using Na-free assay buffer)

$10 \mu \mathrm{l}$ of radioactive stock

$250 \mu \mathrm{l}$ of $20-\mathrm{mM}$ carrier

$4.74 \mathrm{ml}$ sodium-free assay buffer 